Ann. rheum. Dis. (1979), 38, Supplement p. 24

\title{
Long-term follow-up and prognosis of Reiter's syndrome
}

\author{
G. W. CSONKA \\ From St. Mary's Hospital, Paddington, London
}

A number of textbooks and articles suggest that the prognosis of Reiter's syndrome (RS), unlike that of ankylosing spondylitis (AS) and rheumatoid arthritis (RA), is good both in the short- and longterm and that the few deaths occur equally from complications and drug side effects, and are in any event very rare. ${ }^{71}$ I too subscribed to this until I gathered more experience. As I said in my previous paper (see p. 4), a mortality of $0.9 \%$ can be expected in venereal RS. The residual disabilities are the main theme of this paper.

\section{Patients and methods}

One hundred and eighty-five patients with venereal RS seen over a period of 3-18 years (mean 8.6 years) were sent a questionnaire and asked to attend for follow-up studies. Out of 125 who replied 50 were seen and examined. Out of the 75 who completed the questionnaire but did not attend $45(60 \%)$ wrote that they had further, usually mild attacks of RS and five had pronounced residual symptoms which were incapacitating. Of the 50 examined, 31 had had no further attacks and $19(28 \%)$ had had further episodes and some residual disabilities. Thus a total of 125 patients (121 men and 4 women) are included in this study.

This is not an unselected group since early defaulters are known to contain a high proportion of mild and short illness. ${ }^{69}$ Also, owing to my known interest in this condition, I was sent a small number of the more difficult and severe cases. The response to the questionnaire and attendance also indicated that those who thought themselves to be more ill were more likely to reattend for examination.

\section{Results}

Of the 50 patients re-examined 31 had had no further attacks in the intervening years. All of the $19(38 \%)$ with further activity had some degree of residual disabilities such as recurrent iritis with visual loss (4 cases); chronic deformed and painful feet (11 cases); and persistent backache, morning stiffness, and radiological sacroiliitis (4 cases). Four patients among the 19 with active disease had systemic visceral disease affecting the cardiac system ( 2 cases) or the central nervous system ( 2 cases).

A total of $64(51 \cdot 1 \%)$ of the 125 patients had more than one attack during the observation period. A representative selection is shown in Fig. 1. Including known attacks before the follow-up period, 112 $(60.5 \%)$ of the original 185 had a remittingrelapsing course, with the longest remission between attacks of 36 years.

We studied in detail in 82 patients the number of recurrent attacks (Table 1) and the risk of a first recurrence by duration after the initial attack (Table 2). The results show that one to two recurrent attacks were the most common, but up to seven were seen in this series. The percentage risk of a recurrent attack remained fairly uniform over a great many years and was substantial throughout the observation period. The practical implication of this finding could be that prophylactic measures should operate for a prolonged period, possibly for life, especially in patients known to have HLAB27 antigen.*

Recurrences tended to repeat the clinical pattern of the first attack, as illustrated by the recurrence of eye lesions during relapses (Table 3 and Fig. 2).

Table 1 Distribution of cases according to number of recurrent attacks of Reiter's syndrome

\begin{tabular}{lll}
\hline Recurrent episodes & No. of cases & $\begin{array}{l}\text { Person-years } \\
\text { observation }\end{array}$ \\
\hline None & 38 & $197 \cdot 5$ \\
1 & 17 & $121 \cdot 5$ \\
2 & 12 & $144 \cdot 0$ \\
3 & 4 & $47 \cdot 5$ \\
4 & 6 & $80 \cdot 0$ \\
5 & 2 & $40 \cdot 5$ \\
6 & 2 & $40 \cdot 0$ \\
7 & 1 & $15 \cdot 0$ \\
\hline Total & 82 & $686 \cdot 0$ \\
\hline
\end{tabular}

*Assuming that recurrences are due to reinfection-Editor. 

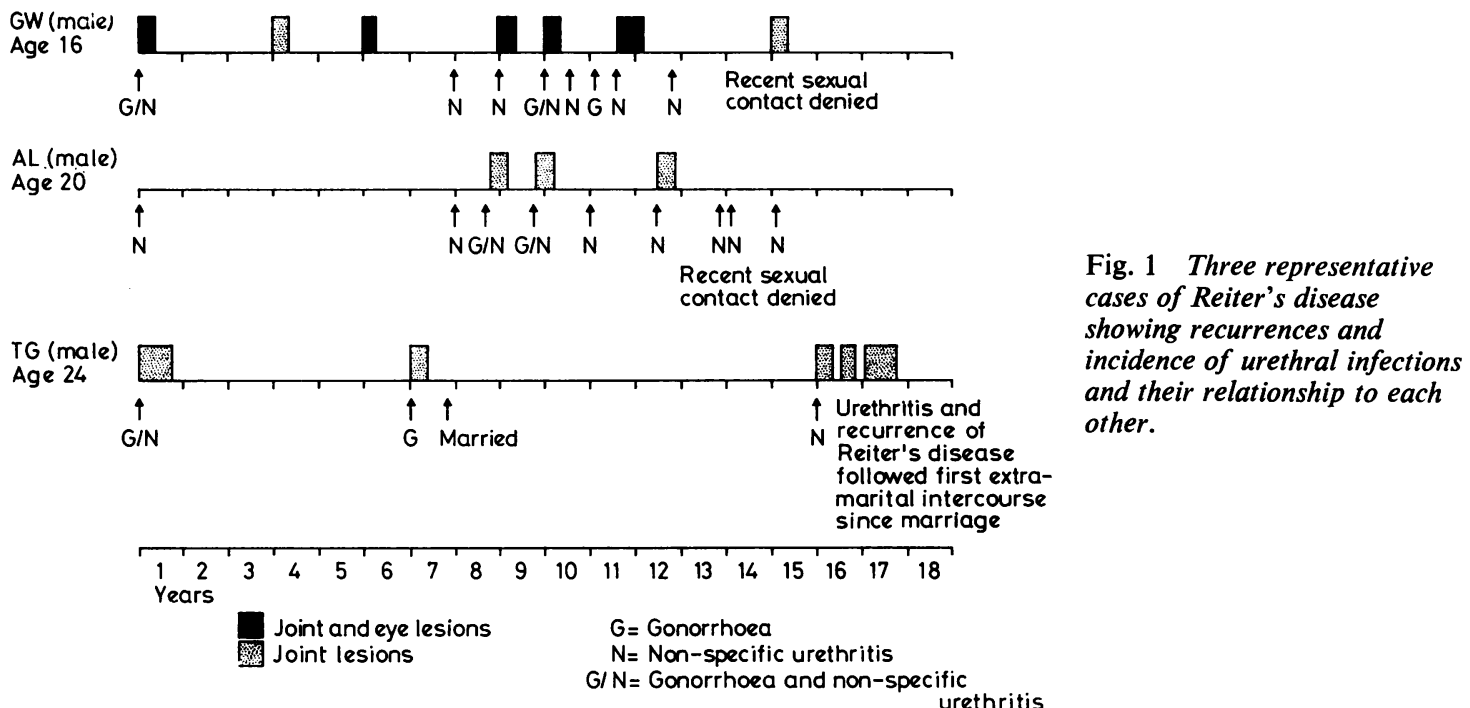

onset and recurrence rate, but for a trend towards fewer recurrences in patients whose syndrome started at an older age (Table 4).

Table 2 Risk of a first recurrence of Reiter's syndrome by duration after onset

\begin{tabular}{llll}
\hline $\begin{array}{l}\text { No. of years } \\
\text { after onset }\end{array}$ & $\begin{array}{l}\text { No. of persons } \\
\text { at risk }\end{array}$ & $\begin{array}{l}\text { First recurrent } \\
\text { attack }\end{array}$ & $\begin{array}{l}\text { Percentage risk } \\
\text { of first recurrent } \\
\text { attack }\end{array}$ \\
\hline $0-$ & 75 & 13 & $17 \cdot 3$ \\
$1-$ & 62 & 6 & $9 \cdot 7$ \\
$2-$ & 54 & 7 & $13 \cdot 012 \cdot 2$ \\
$3-$ & 45 & 4 & $8 \cdot 8$ \\
$4-$ & 36 & 4 & $11 \cdot 1$ \\
$5-$ & 25 & 2 & $8 \cdot 0$ \\
$6-$ & 17 & 1 & $6 \cdot 0$ \\
$7-$ & 15 & 1 & $6 \cdot 37 \cdot 5$ \\
$8-$ & 13 & 2 & $15 \cdot 4$ \\
$9-$ & 10 & - & - \\
\hline $10+$ & 9 & 4 & $44 \cdot 4$ \\
\hline
\end{tabular}

Rcenrrence rate (attacks) is based on the number of episodes occurring; the denominator is the number of person-years observations.
The relationship of urethral infection to recurrent attacks is not a simple one, as seen in Fig. 1. Unlike in first attacks, the close association of urethritis and arthritis or urethritis and iritis seen at onset was less pronounced during relapses. Thus urethritis was conspicuously absent in $41.9 \%$ of all recurrent episodes (Table 5), suggesting that a sizeable proportion of recurrences were relapses rather than

Table 3 Distribution of first attacks and recurrence rates according to presence or absence of eye lesions at onset

\begin{tabular}{|c|c|c|c|c|c|}
\hline \multirow{2}{*}{$\begin{array}{l}\text { Eye lesion } \\
\text { at onset }\end{array}$} & \multirow{2}{*}{$\begin{array}{l}\text { No. of } \\
\text { cases }\end{array}$} & \multicolumn{3}{|c|}{ Cases with recurrent attacks } & \multirow{2}{*}{$\begin{array}{l}\text { Person- } \\
\text { years } \\
\text { observation }\end{array}$} \\
\hline & & No. & $\begin{array}{l}\text { With eye } \\
\text { lesions }\end{array}$ & $\begin{array}{l}\text { Without } \\
\text { eye lesions }\end{array}$ & \\
\hline $\begin{array}{l}\text { Present } \\
\text { Absent }\end{array}$ & $\begin{array}{l}32 \\
50\end{array}$ & $\begin{array}{l}16 \\
28\end{array}$ & $\begin{array}{l}11 \\
10\end{array}$ & $\begin{array}{r}5 \\
18\end{array}$ & $\begin{array}{l}210 \cdot 5 \\
475 \cdot 5\end{array}$ \\
\hline Totals & 82 & 44 & 21 & 23 & 686.0 \\
\hline
\end{tabular}

Table 4 Distribution of single attacks and recurrence according to age of patient at onset of Reiter's syndrome.

\begin{tabular}{|c|c|c|c|c|c|c|}
\hline $\begin{array}{l}\text { Age at onset } \\
\text { (years) }\end{array}$ & $\begin{array}{l}\text { Total no. of } \\
\text { patients }\end{array}$ & $\begin{array}{l}\text { Patients with } \\
\text { single attacks }\end{array}$ & $\begin{array}{l}\text { Person-years } \\
\text { observation }\end{array}$ & $\begin{array}{l}\text { Patients with } \\
\text { recurrent attacks }\end{array}$ & $\begin{array}{l}\text { Person-years } \\
\text { observation }\end{array}$ & $\begin{array}{l}\text { Recurrence } \\
\text { rate (attack) }\end{array}$ \\
\hline $\begin{array}{l}15- \\
20- \\
25- \\
30- \\
35- \\
40- \\
45- \\
50+\end{array}$ & $\begin{array}{r}5 \\
16 \\
20 \\
13 \\
12 \\
17 \\
5 \\
3\end{array}$ & $\begin{array}{r}1 \\
4 \\
11 \\
8 \\
5 \\
4 \\
3 \\
2\end{array}$ & $\begin{array}{r}2 \cdot 0 \\
18 \cdot 5 \\
73 \cdot 5 \\
42 \cdot 0 \\
46 \cdot 5 \\
31 \cdot 0 \\
17 \cdot 0 \\
5 \cdot 0\end{array}$ & $\begin{array}{r}4 \\
12 \\
9 \\
5 \\
7 \\
3 \\
2 \\
1\end{array}$ & $\begin{array}{r}56 \cdot 0 \\
130 \cdot 0 \\
119 \cdot 5 \\
71 \cdot 0 \\
39 \cdot 5 \\
26 \cdot 5 \\
5 \cdot 5 \\
2 \cdot 5\end{array}$ & $\begin{array}{r}6 \cdot 9 \\
8 \cdot 0 \\
4 \cdot 6 \\
4 \cdot 4 \\
8 \cdot 0 \\
5 \cdot 3 \\
9 \cdot 0 \\
13 \cdot 3\end{array}$ \\
\hline Totals & 82 & 38 & $235 \cdot 5$ & 44 & $450 \cdot 5$ & \\
\hline
\end{tabular}




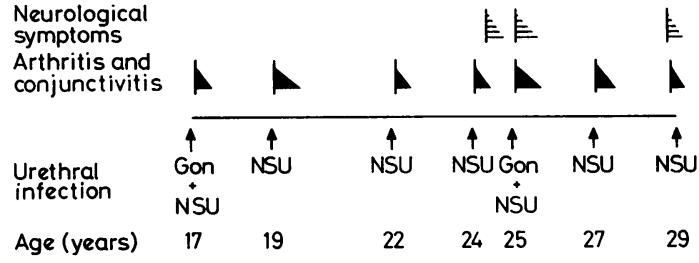

Fig. 2 Incidence of recurrences in a patient with Reiter's syndrome.

Table 5 Presence or absence of urethritis at time of first attack. Possibly those without obvious urethritis represent relapses rather than new attacks

\begin{tabular}{|c|c|c|c|}
\hline Urethritis & $\begin{array}{l}\text { Associated } \\
\text { with initial } \\
\text { attack of } \\
\text { Reiter's } \\
\text { syndrome }\end{array}$ & $\begin{array}{l}\text { Associated } \\
\text { with recurrent } \\
\text { attacks of } \\
\text { Reiter's } \\
\text { syndrome }\end{array}$ & $\begin{array}{l}\text { Urethritis } \\
\text { recurring without } \\
\text { Reiter's } \\
\text { syndrome }\end{array}$ \\
\hline \multirow{4}{*}{$\begin{array}{l}\text { Gonorrhoea } \\
\text { Non-specific } \\
\text { urethritis } \\
\text { Gonorrhoea and } \\
\text { non-specific } \\
\text { urethritis } \\
\text { No urethritis }\end{array}$} & 14 & 5 & 16 \\
\hline & 36 & 47 & 22 \\
\hline & 32 & 9 & 3 \\
\hline & - & 44 & - \\
\hline Totals & 82 & 106 & 41 \\
\hline
\end{tabular}

fresh attacks. This accords with the claim of many patients that some recurrent episodes, in contrast with the first one, occurred during periods of sexual abstinence. In others an attack seemed to coincide with or be provoked by sexual intercourse and was indistinguishable from the first attack. Some patients had both forms of recurrent episodes. The picture is made more complex by the fact that not every freshly acquired urethral reinfection precipitated a further attack of RS. Moreover, a number of patients had several attacks of gonococcal or non-specific urethritis, or both, long before the onset of RS.

Sacroiliitis was associated with more severe disease, and the less common spondylitis was atypical and often relatively asymptomatic. These residual features led to various degrees of disability both at

Table 6 Working capacity of 125 patients with Reiter's syndrome followed for 3-18 years

\begin{tabular}{lr}
\hline Degree of disability & No. $(\%)$ \\
\hline None & $106(84 \cdot 8)$ \\
Mild & $9(7 \cdot 2)$ \\
Moderate & $5(4 \cdot 0)$ \\
Severe* & $5(4 \cdot 0)$ \\
\hline
\end{tabular}

*Includes four with visceral lesions, one of whom died. work and leisure. Nine patients were mildly incapacitated, five had moderate disabilities, and five were severely handicapped (Table 6). This left $84 \cdot 2 \%$ of patients with full working capacity.

\section{Discussion}

The possibility of recurrences posed a constant threat in these patients. As recurrences not infrequently lead to permanent disabilities, quite apart from the unpleasantness of the recurrent attack itself, all efforts to establish effective prophylaxis would be welcome. But since some attacks develop unprovoked by sexual intercourse even protected intercourse might at best have only partial prophylactic value.

Whether treatment of urethritis at the earliest possible moment might prevent the development of RS initially or subsequently or both, has not been properly researched. It might be worth the effort, as would the clarification of the relationship between finding such pathogens as Chlamydia, genital mycoplasmas, genital corynebacterium, and others to subsequent events.

Our experience of prognosis in venereal RS is similar to that reported from the large Finnish series of postdysenteric RS. It indicates that RS, be it venereally acquired or associated with bacillary dysentery, leads to disabilities in later life in $30 \%$ $40 \%$ of cases and that the ever-present threat of a recurrence must also be taken into account. Serious systemic lesions can be expected in over $3 \%$ of patients, and the overall mortality appears to be just under $1 \%$. For all these reasons there is urgency in improving the outlook for those at risk in developing RS.

\section{General discussion}

PROF. V. WRIGHT: Dr. Csonka is to be congratulated on trying to follow up this notoriously unstable population. One is a little worried epidemiologically, of course. Isn't there a major selection bias in the 50 submitted to long term follow-up?

DR. CSONKA: We did not select the 50, they came of their own free will. They clearly selected themselves and are likely to be more seriously ill, so the selection was theirs not ours.

DR. E. ALBERT: You spoke about the rate of recurrences in the patients that come to see a venereologist. Is it any different from the rate in patients seen by a rheumatologist? Compared with venereologists, I believe rheumatologists see relatively few patients with RS.. 
DR. CSONKA: Well, I can hardly answer this because I am not a rheumatologist. In the present climate of sexual freedom in the United Kingdom we have 200 VD clinics-indeed, the only country in the world where there is a VD service that is free, easily available, confidential, and therefore heavily patronised. Thus 29000 new patients attend my clinic each year, which is quite a lot. So I think that the VD departments see most of the cases of RS as well as simple urethritis.

PROF. R. F. WILLKENS: In 1959 you followed-up a group and described the duration of existence of RS as a no-risk factor for the development of sacroiliitis. You also noted a $20 \%$ incidence of sacroiliitis in that group of 134 . What would be your present thoughts?

DR. CSONKA: As Dr. Martel and others have pointed out, sacroiliitis is very common. Early in the disease backache and early morning stiffness are very common but transient and do not necessarily lead to any sustained or radiological changes later on. On the other hand, radiologically confirmed sacroiliitis was present in a similar proportion in the patients in my first and in my present report. Ankylosing spondylitis, on the other hand, was very much less common, possibly less common than in Dr. Good's series, often atypical and asymptomatic. Typical AS occurred in only about $2 \%$ of our cases, but very often there were other radiological changes such as described by Dr. Martel. We have, of course, seen the odd patient who had AS preceding $\mathrm{RS}$ or vice versa.

PROF. J. STORZ: You studied the visceral manifestations of RS and you mentioned the intestinal tract. What kind of gastrointestinal involvement was there? What history did these patients have? Were there any renal problems in some of these patients?

DR. CSONKA: I can answer the first question but not the last. The first is that intestinal symptoms were almost unknown. I have occasionally been called in to see the patients, some of them children, with intestinal symptoms. I have not followed-up patients who had postdysenteric RS, but then, of course, we are dealing with a different clientele from that seen in North Africa or Finland. I maintain that the venereal type of RS is by far the most common one in the UK. The postdysenteric form certainly occurs in Britain, though rarely. As for your last question about renal involvement. We know little about this, but $I$ suspect it to be rare. The two-glass urine test showed the second glass to contain clear urine, which does not suggest renal involvement. The first glass contained urine full of pus and threads, suggesting an entirely urethral and possibly also prostatic involvement. We have done a few intravenous pyelograms and venograms. They were completely normal, but I am afraid this was a very small series.

DR. J. C. GERSTER: You described aortic insufficiency in patients with RS. What was the percentage in your follow-up cases?

DR. CSONKA: So far there have been only eight cases of aortic incompetence $(1.9 \%)$ out of 410 patients with RS. There may have been some negative selection-patients who might have gone directly to a cardiologist. On the other hand, 98 patients $(24 \%)$ presented with transient cardiovascular signs ranging from ECG changes in heart rhythm to pericarditis but which did not necessarily lead to serious complications later on except for two patients who died, one from aortic regurgitation and heart failure, the other with total heart block.

DR. K. K. BANDILla: The term 'chronic Reiter's disease' has not been introduced this morning. My experience as a rheumatologist is that whenever symptoms do not respond to a heavy anti-inflammatory treatment (eventually even corticosteroids) within about six weeks the disease may go on to develop a chronic form. Chronic forms of RS are then very hard to differentiate from psoriatic arthritis. I wonder what other clinicians think about this. DR. CSONKA: I have seen just what you are describing. In fact, two slides did show chronic illness which went on for many years. Moreover, we have seen patients who had undoubted RS to start with, went on to have psoriatic arthropathy, and were already on a very heavy dosage of corticosteroids and had Cushing's syndrome, osteoporosis, and other drugrelated complications. I suggested that they should be given immunosuppressive drugs to enable the dose of corticosteroids to be lowered, but I do not know what happened to them later. I had been called to see them only once of twice as a consultant physician.

PROF. A. T. MASI: Do you think that recurrences occurred randomly or did you detect any association between, let us say, severity of disease at onset or any other initial feature.with risk of subsequent recurrences? And did you see if there was any association between recurrence rate and presence of B27?

DR. CSONKA: Patients who had eye symptoms or sacroiliitis, or both, usually were in for further trouble by having more severe and more frequent recurrences than those who had only, say, one or two minor and one major feature, so that the more severe the onset the more severe recurrences were 
likely to be. We have tissue typed only about 32 patients. All of them were B27-positive, so I am not in a position to answer that question. Those typed were all fairly severe cases.

PROF. A. S. RUSSELL: Our small series of 38 patients made RS seem a benign disease. We followed them for only six years. I know Dr. Ford feels similarly with a much larger although perhaps less formally reviewed group. This contrasted with Dr. Calin's (Californian) experiences. My initial hypothesis was that this merely reflected a difference between Canadian and Californian physicians, but this obviously does not hold up now. Do you think it is simply that we have not followed our patients long enough or do you think it could really reflect different aetiology (such as that attributed to Chlamydia in California)?

DR. CSONKA: You may have been lucky and seen perhaps 20 to 30 patients in a row who cleared up in a matter of two to three weeks (our average duration for the average attack is about two to three months). But there were cases which we felt needed hospitalisation yet when seen a week or so later they were already convalescing. So I would summarise that until one has seen a great number of cases it is difficult to be too dogmatic about duration. Our experience indicates that it is a disease that must not be taken too lightly. 